\title{
Effect of Extra Curricular Activity on Student's Academic Performance
}

\author{
Ahmad $M^{1}$, Rahman $\mathrm{MF}^{2}$, Ali Mํ, Rahman $\mathrm{FN}^{4}$, Al-Azad MAS ${ }^{5}$
}

\begin{abstract}
Introduction: Extracurricular activities are part and parcel of modern day's academic curriculum. It provides them a positive character building opportunity and teaches ways to develop discipline, commitment, tenacity, self control and a healthy respect for college authority.
\end{abstract}

Objectives: To find out the relation between student's participation in extracurricular activities in college campus and academic performance.

Materials and Methods: This cross sectional study was conducted at Armed Forces Medical College, Dhaka from February 2015 to October 2015. A total of 475 students belonged to four different phase groups were selected as research sample. The dependant variable was fixed at overall improvement in examination results where as independent variables were gender, participation and non participation in all extra academic activities performed at college campus. Research Data were collected from records of training section of the college. Data was analyzed in terms of percentage and Pearson Chi-Square test using SPSS-20 version of software.

Results: Total participant students were 475 and Male female student ratio was 168(35.36\%): 307 $(64.64 \%)$. In outdoor games and sports, males showed better participation than female $121(72.02 \%)$ : $89(28.99 \%)$. But the number of participating female increased in case of indoor games \{male $115(68.45 \%)$ : female $205(66.77 \%)$ \}. Considering photography club participation male showed better response \{male 76(45.23\%): female $41(13.35 \%)\}$. In case of cultural and debate club activities females showed greater response \{female $226(73.61 \%)$ : male 106(63.09\%)\}. In medical carnival club activities female: male score was almost similar \{Female 207(67.43\%): male $112(66.66 \%)\}$. The class attendance (more than $75 \%$ ) of participating students \{male 106(94.64\%) and female $208(92.04 \%)$ ) were much better than non participating students. Regarding result of term finals all the participants showed better academic performance \{male $87(77.68 \%$ ) and female 187 $(82.74 \%)\}$. In Professional MBBS examinations participant 103 (91.96\%) male and 201 (88.94\%) female passed at one chance while percentage of pass was less in non participant students $\{31$ $(55.35 \%)$ male and $44(57.14 \%)$ female $\}$. Pearson Chi-Square test result showed significance in all the above aspects.

Conclusion: Students participating in extracurricular activities generally benefit from having better examination results, higher self concept, higher standardized test scores and educational attainment. Students often learned skills such as teamwork and leadership from college club activities while decreasing the likelihood of different problem behaviors.

Key-words: Student, Extracurricular activity, Academic performance.

\begin{abstract}
Introduction
Extracurricular activities are part and parcel of modern day's academic curriculum. Students keep themselves involved in games, sports and cultural activities to nourish their knowledge, attitude and skill. Although it is difficult for medical students to spend some time for extracurricular activities out of their busy academic schedule and ward placement. But those who are regularly participating in different items get the opportunity to face challenges, alternative resources and lifelong learning experiences. However
\end{abstract}

1. Lt Col Mushtaq Ahmad, MBBS, DFM, MCPS, FRSPH, Associate Professor and Head, Dept of Forensic Medicine, AFMC, Dhaka 2. Maj Gen Md Fashiur Rahman, ndc, MBBS, MPH, LLB, FCGP, MBA, MSS, Commandant, AFMC, Dhaka 3. Brig Gen Mohammad Ali, MBBS, DPH, MPhil, Professor and Head, Dept of Community Medicine, AFMC, Dhaka 4. Dr Farial Naima Rahman, MBBS, DMU, Lecturer, Dept of Forensic Medicine, AFMC, Dhaka 5. Lt Col Md Abdus Samad Al-Azad, MBBS, DFM, MCPS, Assistant Professor, Dept of Forensic Medicine, AFMC, Dhaka. 
there is always a question whether extra academic activities in college campus has some beneficial effect on students academic performance or not?

Holson stated, "There is a positive correlation between student involvement in extracurricular activities and success in nonacademic pursuits following high school and college"1. It is evident that students who participate well in these activities have greater success in academic institutions, as well as, later in life. Another study by Joekel RG showed that achievement in extracurricular activities is a factor that can predict success in life beyond college ${ }^{2}$. Stephens and Schaben suggested that "educators should encourage students to be involved in interscholastic sports and cultural activities" ${ }^{3}$. Gardner et al. in his research on positive youth development suggested that cultivating positive, supportive relationships with people and social institutions encourages healthy development of learners. Students who participate in structured activities are more likely to respect diversity, play by the rules and contribute as a member of a team whether it is sports, scouting or clubs ${ }^{4}$. This study was performed to find out the relationship between student's participation in extracurricular activities in college campus and academic performance.

\section{Materials and Methods}

This cross sectional study was conducted at Armed Forces Medical College (AFMC), Dhaka from February 2015 to October 2015. A total of 475 students belonged to four different phase groups were selected as research sample. The dependant variable was fixed at term final and different professional examination results, class performance of students in recalling of knowledge and information. Whereas independent variables were gender, participation and non participation in extra academic activities performed at college campus. These extra academic activities include Sports club activitiesoutdoor games, Indoor games, Cultural and debate club activities (dance, song, recitation, drama, extempore speech, debate), Photography club activities, Medical carnival club activities (doctors dilemma, case presentation, medi-spelling, medi-quiz, meidcal poster, medical cartoon, integrated teaching programme, problem based learning). Necessary ethical permission was taken from concerned authority for this research. Research Data were collected from records of training section of the college. Students were purposively interviewed to cross check the information. Data was analyzed in terms of percentage and Pearson Chi-Square test using SPSS-20 version of software.

\section{Results}

Total male students from Phases 1, 2, 3 and 4 were 42, 40, 47 and 39 respectively. Number of female student were $83,85,79$ and 60 from 4 phases respectively (Table-I). Male and female student ratio in this study was 168(35.36\%): 307(64.64\%).

Table-I: Distribution of students from different phases by sex $(n=475)$

\begin{tabular}{|l|c|c|c|c|c|}
\hline Student & Phase-1 f(\%) & Phase-2 f(\%) & Phase-3 f(\%) & Phase-4 f(\%) & Total f(\%) \\
\hline Male & $42(33.60 \%)$ & $40(32 \%)$ & $47(37.30 \%)$ & $39(39.40 \%)$ & $168(35.36 \%)$ \\
\hline Female & $83(66.40 \%)$ & $85(68 \%)$ & $79(62.70 \%)$ & $60(60.60 \%)$ & $307(64.64 \%)$ \\
\hline Total & $125(100 \%)$ & $125(100 \%)$ & $126(100 \%)$ & $99(100 \%)$ & $475(100 \%)$ \\
\hline
\end{tabular}

Considering participation in outdoor games and sports, males showed better result than female 121(72.02\%): 89(28.99\%) (Fig-1).

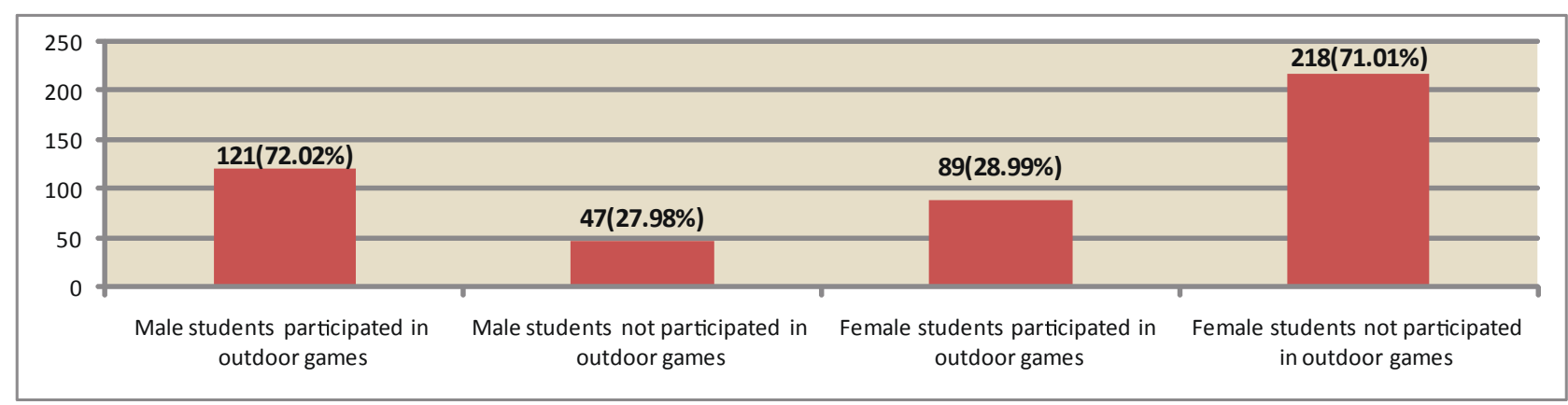

Fig-1: Distribution of male and female participants in outdoor games $(n=475)$ 
But the percentage of participating female student increased in case of indoor games \{male 115(68.45\%): female $205(66.77 \%)$, since the variety of games were equal in this case (Fig-2).

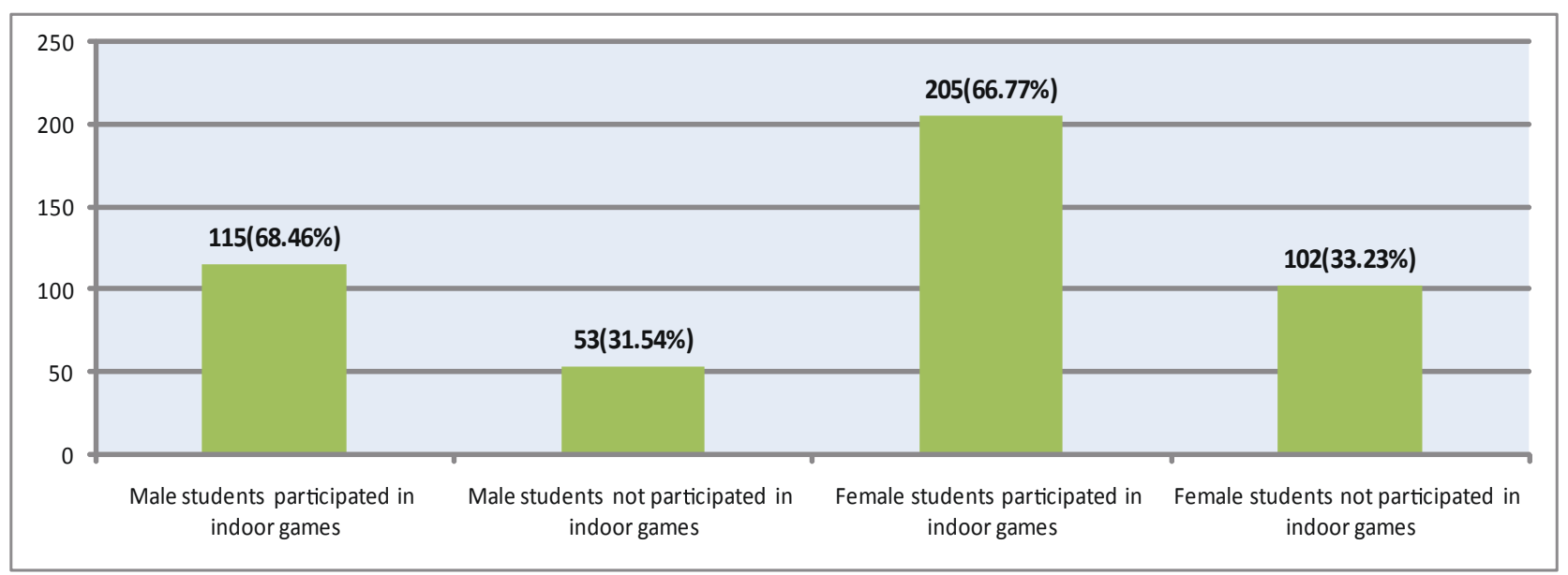

Fig-2: Total number of male and female participants in indoor games

Considering photography club participation male showed better participation \{male $76(45.23 \%)$ : female $41(13.35 \%)\}$. In case of cultural \& debate club activities females showed greater response ffemale 226 (73.61\%): male 106(63.09\%)\}. In medical carnival club activities female: male ratio was almost similar. \{female 207(67.43\%) : male112(66.66\%) \} (Table-II).

Table-II: Frequency distribution of students participation in club activities $(n=475)$

\begin{tabular}{|l|c|c|c|}
\hline Group & $\begin{array}{c}\text { Photography club } \\
\text { activities f(\%) }\end{array}$ & $\begin{array}{c}\text { Cultural \& Debate } \\
\text { club activities f(\%) }\end{array}$ & $\begin{array}{c}\text { Medical Carnival } \\
\text { Club activities f(\%) }\end{array}$ \\
\hline Male students participated & $76(45.23 \%)$ & $106(63.09 \%)$ & $112(66.66 \%)$ \\
\hline Male students not participated & $92(54.77 \%)$ & $62(36.91 \%)$ & $56(33.34 \%)$ \\
\hline Female students participated & $41(13.35 \%)$ & $226(73.61 \%)$ & $207(67.43 \%)$ \\
\hline Female students not participated & $266(86.65 \%)$ & $81(26.39 \%)$ & $100(32.57 \%)$ \\
\hline
\end{tabular}

The class attendances of participating students were much better than non participant students. Male 106 $(94.64 \%)$ and female 208 (92.04\%) participant students had percentage of attendance more than $75 \%$, whereas male $25(44.64 \%)$ and female $36(46.75 \%)$ non participant had percentage of attendance more than $75 \%$ (Table-III). Pearson Chi-Square test (Table-III) showed significance result in statistical analysis.

Table-III: Frequency distribution of students class attendance $(n=475)$

\begin{tabular}{|c|c|c|c|}
\hline Status & $\begin{array}{l}\text { Class attendance } \\
\text { more than } 75 \% \mathrm{f}(\%)\end{array}$ & $\begin{array}{l}\text { Class attendance } \\
\text { less than } 75 \% \mathrm{f}(\%)\end{array}$ & Statistical analysis \\
\hline $\begin{array}{l}\text { Male students participated } \\
\text { in extracurricular activities (112) }\end{array}$ & $106(94.64 \%)$ & $06(5.36 \%)$ & \multirow{2}{*}{$\begin{array}{c}\text { Chi Square static is } \\
54.3478 p \text {-value } \\
\text { is }<0.00001\end{array}$} \\
\hline $\begin{array}{l}\text { Male students not participated } \\
\text { in any extracurricular activities (56) }\end{array}$ & $25(44.64 \%)$ & $31(55.36 \%)$ & \\
\hline $\begin{array}{l}\text { Female students participated } \\
\text { in extracurricular activities (226) }\end{array}$ & $208(92.04 \%)$ & $18(7.96 \%)$ & \multirow{2}{*}{$\begin{array}{c}\text { Chi Square static is } \\
75.1024 p \text {-value } \\
\text { is }<0.00001\end{array}$} \\
\hline $\begin{array}{l}\text { Female students not participated } \\
\text { in any extracurricular activities (77) }\end{array}$ & $36(46.75 \%)$ & $41(53.25 \%)$ & \\
\hline
\end{tabular}

Regarding result of term finals/ professional examinations, all the participants showed better academic performance than the non participants. In the term final examination participant male $87(77.68 \%)$ and female $187(82.74 \%)$ qualified at one chance while non-participant male $22(39.28 \%)$ and female $37(48.05 \%)$ passed the exam at first time (Table-IV). In Professional MBBS examinations participant male 103 (91.96\%) and female 
student 201 (88.94\%) passed at one chance, among non participant students male 31 (55.35\%) and female 44 $(57.14 \%)$ passed the exam at one chance (Table-V). Pearson Chi-Square test showed significance result in statistical analysis.

Table-IV: Frequency distribution of students status of Term final examination results $(n=475)$

\begin{tabular}{|c|c|c|c|}
\hline Status & $\begin{array}{c}\text { Passed in Term final } \\
\text { examination at one } \\
\text { chance } \mathrm{f}(\%)\end{array}$ & $\begin{array}{c}\text { Did not pass in } \\
\text { Term final examination } \\
\text { at one chance } f(\%)\end{array}$ & Statistical analysis \\
\hline $\begin{array}{l}\text { Male students participated in } \\
\text { extracurricular activities (112) }\end{array}$ & $87(77.68 \%)$ & $25(22.32 \%)$ & \multirow{2}{*}{$\begin{array}{l}\text { Chi Square static } \\
\text { is } 24.1511 p \text { - value } \\
\text { is }<0.00001\end{array}$} \\
\hline $\begin{array}{l}\text { Male students not participated in } \\
\text { any extracurricular activities (56) }\end{array}$ & $22(39.28 \%)$ & $34(60.72 \%)$ & \\
\hline $\begin{array}{l}\text { Female students participated in } \\
\text { extracurricular activities (226) }\end{array}$ & 187 (82.74\%) & $39(17.26 \%)$ & \multirow{2}{*}{$\begin{array}{l}\text { Chi Square static } \\
\text { is } 35.86 p \text {-value } \\
\text { is }<0.00001\end{array}$} \\
\hline $\begin{array}{l}\text { Female students not participated in } \\
\text { any extracurricular activities (77) }\end{array}$ & $37(48.05 \%)$ & $40(51.95 \%)$ & \\
\hline
\end{tabular}

Table-V: Frequency distribution of students status of professional MBBS examination results $(n=475)$

\begin{tabular}{|l|c|c|c|}
\hline Status & $\begin{array}{c}\text { Passed in Professional } \\
\text { MBBS examination at } \\
\text { one chance f(\%) }\end{array}$ & $\begin{array}{c}\text { Did not pass in } \\
\text { Professional MBBS } \\
\text { examination at one } \\
\text { chance f(\%) }\end{array}$ & Statistical analysis \\
\cline { 1 - 3 } $\begin{array}{l}\text { Male students participated in } \\
\text { extracurricular activities (112) }\end{array}$ & $103(91.96 \%)$ & $9(8.04 \%)$ & $\begin{array}{c}\text { Chi Square static } \\
\text { is } 30.993 p \text {-value } \\
\text { is }<0.00001\end{array}$ \\
\cline { 1 - 3 } $\begin{array}{l}\text { Male students not participated in } \\
\text { any extracurricular activities (56) }\end{array}$ & $31(55.35 \%)$ & $25(44.65 \%)$ & $\begin{array}{c}\text { Chi Square static } \\
\text { is } 23.5104 p \text {-value } \\
\text { is }<0.00001\end{array}$ \\
\hline $\begin{array}{l}\text { Female students participated in } \\
\text { extracurricular activities (226) }\end{array}$ & $201(88.94 \%)$ & $39(17.26 \%)$ & $33(42.86 \%)$ \\
\cline { 1 - 2 } $\begin{array}{l}\text { Female students not participated in } \\
\text { any extracurricular activities (77) }\end{array}$ & $44(57.14 \%)$ & & \\
\hline
\end{tabular}

\section{Discussion}

The term 'extracurricular activities' refers to any activities that take place outside of the regular (compulsory) curriculum. "The activities are voluntary and students do not receive grades for academic credit for them" of class hours but within the institutional setting. Gilman discussed the concept of structured extracurricular activities as a strategy for colleges to build resiliency, offer opportunities for engagement with educational institute activities and provide constructive academic performance ${ }^{6}$. Different terms like extracurricular activities, co-curricular activities and non-classroom activities have all been used interchangeably to mean experiences and activities such as games and sports, debate, music, drama, college publications, student clubs, contests and various social events ${ }^{7,8,9}$. Several ground-breaking studies on this topic performed by Astin; Tinto and Pascarella and Terenzini suggested that there is a positive correlation between student engagement, learning and persistence $e^{10,11,12}$. In this study, male and female student ratio was 168(35.36\%): 307 (64.64\%), because majority of students are female in this institute. Considering participation in outdoor games and sports, males showed better result than female because outdoor games facilities were more available to male students, whereas female had only volleyball to play during afternoon. But the ratio was almost similar in case of indoor games, since the availability of different games was equal in this case.

Darling and Marsh showed in their study that student athlete's interaction with each other may contribute to development of self-identity ${ }^{13,14}$. A student's identification and involvement with sports creates a social network that emphasizes the value of the institution, academics and continuing their education after graduation ${ }^{15}$. A survey on 4,800 students in Minnesota discovered that 91 percent of 
of the students reported those who participate in athletics and activities tend to be the leaders and role models in the institution. Ninety-two percent reported that games and sports provided an opportunity to develop self-discipline ${ }^{16}$.

Considering photography club participation male shows better participation, since a greater part photo shooting took place outside campus in natural scenario and female students had some restriction to go outside. In case of medical carnival females showed greater response, because numbers of female students were more and they had equal opportunity with male students in college campus. Regarding result of term finals/ professional examinations, all the participants showed better academic performance than the non participant's. This coincides with studies of Eccles, Daley and Leahy who showed extracurricular activities facilitates the acquisition of interpersonal skills and positive social norms, stronger emotional and social connections to one's educational institute. An increase of wellness in mental health, improved students' engagement in school and achievement, strengthen their long-term educational outcomes; influence the mental well-being of young people by reducing stress ${ }^{17,18}$.

In this study students who participated in extracurricular activities had better attendance rate (more than $75 \%$ ) in class. This coincides with study of McCarthy, who highlighted that students participated in extracurricular activities have significantly lower absenteeism and higher GPA's ${ }^{19}$. Fredrick's and Eccles also found that activity participation can be linked to positive academic outcomes, improved grades, test scores, more engagement in class, less absenteeism and increased educational aspirations ${ }^{20}$.

Broh, Holland and Coleman in their study have showed that there may be no significant advantages in academic achievement with participation in extracurricular activities $^{21-23}$. However the present study did not find any negative impact of extracurricular activities on student's academic performance. The results of participant students in term final and professional MBBS examinations were also satisfactory in comparison to non participant students. This result coincides with previous studies of Morrissey, where he stated that there is an established link between adolescents' extracurricular activities, educational attainment, better result and reduction in delinquency ${ }^{24}$. Extracurricular activities help students to stay away from violent or risky behavior and teach to walk through positive pathway for future career building $^{25}$. It is important for teachers and guardians to know the overall impact of participation in extracurricular activities. This information can help families to make wiser choices for creating balance in academics outdoor activities and future career planning in a student's life.

\section{Conclusion}

Students who participate in extracurricular activities generally benefit from having better examination results, having higher standardized test scores and higher educational attainment, attending class more regularly and having higher self concept. Students often learned skills such as teamwork and leadership from college club activities while decreasing the likelihood of different problem behaviors. It is suggested that all educational institute authorities should provide adequate facilities for the students to take part in extracurricular activities within the institute premises and outside schedule class hour.

\section{References}

1. Gholson RE. Student achievement and cocurricular participation. NASSP Bulletin 1985; 69(483):17-20.

2. Joekel RG. Student activities and academic eligibility requirements. NASSP Bulletin 1985; 69(483):3-9.

3. Stephens LJ, Schaben LA. The effect of inter-scholastic sports participation on academic achievement of middle school students. NASSP Bulletin 2002; 86(630):35-41.

4. Gardner M, Roth J, Brooks G. Adolescents' participation in organized activities and developmental success 2 and 8 years after high school: Do sponsorship, duration and intensity matter? Developmental Psychology 2008; 44(3):814-30.

5. Holloway JH. "Extracurricular Activities: The Path to Academic Success?" Association for Supervision and curriculum Development. December 1999:87-8. [cited 18 August 2016] Retrieved from <http://www. cedarvalleychristianschool.org/ Handbook/ Extracurricular Activities/tabid/128/ efault.aspx>. 
6. Gilman R. Structured extracurricular activities among adolescent findings and implications for school psychologists. Psychology in the Schools 2004; 41(1):4-9. The case for high school activities. National Federation of State High School Association. [Cited 2016 May 17] <Retrieved from: www.nfhs. org/case.htm>

7. Emmer R. Band, 1ST ed. New York; Rosen Publishing Group 2010; 24-37.

8. Emmer R. Cheerleading, 1st ed. New York; Rosen Publishing Group 2010; 58-65.

9. Stoltzfus, Corbin D. "A Study of the Correlation Between Participation in Extracurricular Activities and Academic Performance of Middle Level and High School Students" (MA Thesis) The Pennsylvania State University 2007; 21-42.

10. Astin AW. Achieving educational excellence: A critical assessment of priorities and practices in higher education. 1sted. SanFrancisco: Jossey-Bass1985; 54-66.

11. Tinto V. Leaving College: Rethinking the Causes and Cures of Student Attrition, 2nd Ed. Chicago: The University of Chicago Press 1993; 24-32.

12. Pascarella ET and Terenzini PT. How College Affects Students; A Third Decade of Research. 2nd Ed. San Francisco, CA: Jossey-Bass 2005; 24-45.

13. Darling N, Caldwell L, Smith R. Participation in school -based extracurricular activities and adolescent adjustment. Journal of Leisure Research2005; 37(1):51-76.

14. Marsh HW \& Kleitman S. Extracurricular school activities: The good, the bad, and the non-linear. Harvard Educational Review 2002; 72:464-514.

15. Smith SL. Athletics \& Academics. 1st ed. Research Starters. New York 2008; 58-78.

16. The case for high school activities-2002. National Federation of State High School Association. [cited 2016 12 August] Retrieved from: <www.nfhs.org/case.htm>
17. Eccles J. Extracurricular activities and adolescent development. Journal of Social Issues 2003; 59(4): 865-89.

18. Daley A, Leahy J. Self-perceptions and participation in extracurricular physical activities. The Physical Educator 2003; 60(2):13-9.

19. McCarthy, Kevin J. The Effects of Student Activity Participation, Gender, Ethnicity and SocioEconomic Level on High School student Grade Point Averages and Attendance. 1st ed. New York. National Association of African American Studies \& National Association of Hispanic and Latino Studies 2000; 410-24.

20. Fredricks L, Eccles I. Is extracurricular participation associated with beneficial outcomes? Concurrent andl ongitudinal relations. Developmental Psychology 2006; 42(4):698-713.

21. Broh, B. Linking extracurricular programming to academic achievement: Who benefits and why? Sociology of Education 2002; 75(1):69-95.

22. Holland A, Andre T. The effects of participation in extracurricular activities in secondary school: What is known, what needs to be known? Review of Educational Research 1987; 57:437-66.

23. Coleman JS. The adolescent society the social life. 1st ed. New York: Free Press 1961; 87-98.

24. Morrissey K. The relationship between out-ofschool activities and positive youth development: An investigation of the influences of communities and family. Adolescence 2005; 40:67-85.

25. Barber B, Eccles J, Stone M. Whatever happened to the jock, the brain and the princess: Young adult pathways linked to adolescent activity involvement and social identity. Journal of Adolescent Research 2001; 16(5):429-55. 